\title{
On the spatial coherence of rainfall over the Saloum delta (Senegal) from seasonal to decadal time scales
}

OPEN ACCESS

Edited by:

Belen Rodriguez-Fonseca, Universidad Complutense de Madrid,

Spain

Reviewed by:

Eduardo Zorita,

Hemlholtz-Zentrum Geesthacht,

Germany

Daniel F. Nadeau,

Polytechnique Montreal, Canada

*Correspondence:

Malick Wade,

Laboratory of Physics of the Atmosphere and Ocean Simeon

Fongang, Cheikh Anta Diop University,

BP 5085 Dakar-Fann, Senegal malick172@yahoo.fr

Specialty section

This article was submitted to Atmospheric Science,

a section of the journal

Frontiers in Earth Science

Received: 27 February 2015 Accepted: 28 May 2015

Published: 23 June 2015

Citation:

Wade M, Mignot J, Lazar A, Gaye AT and CarréM (2015) On the spatial coherence of rainfall over the Saloum delta (Senegal) from seasonal to decadal time scales.

Front. Earth Sci. 3:30

doi: 10.3389/feart.2015.00030

\begin{abstract}
Malick Wade ${ }^{1 *}$, Juliette Mignot ${ }^{2,3,4}$, Alban Lazar ${ }^{4}$, Amadou T. Gaye ${ }^{1}$ and Matthieu Carré ${ }^{5}$
${ }^{1}$ Laboratory of Physics of the Atmosphere and Ocean Simeon Fongang, Cheikh Anta Diop University, Dakar, Senegal, ${ }^{2}$ Climate and Environmental Physics, Physics Institute, University of Bern, Bern, Switzerland, ${ }^{3}$ Oeschger Centre for Climate Change Research, University of Bern, Bern, Switzerland, ${ }^{4}$ LOCEAN Laboratory, IRD-UPMC-CNRS-MNHN, Sorbonne Universités (Univ. Paris VI), Paris, France, ${ }^{5}$ Institut des Sciences de l'Evolution de Montpellier, Université de Montpellier, CNRS, IRD, Ecole pratique des hautes études, Montpellier, France
\end{abstract}

A paleoreconstruction of the length and intensity of the rainy season over western Africa has been recently proposed, using analysis of fossil mollusk shells from the Saloum delta region, in western Senegal. In order to evaluate the significance of local long-term reconstructions of precipitations from paleoclimate proxies, and to better characterize the spatial homogeneity of rainfall distribution in northern Africa, we analyze here the spatial representativeness of rainfall in this region, from seasonal to decadal timescales. The spatial coherence of winter episodic rainfall events is relatively low and limited to surrounding countries. On the other hand, the summer rainfall, associated with the West African Monsoon, shows extended spatial coherence. At seasonal timescales, local rainfall over the Saloum is significantly correlated with rainfall in the whole western half of the Sahel. At interannual and longer timescales, the spatial coherence extends as far as the Red Sea, covering the full Sahel region. This spatial coherence is mainly associated to the zonal extension of the Inter Tropical Convergence Zone (ITCZ). Coherently, summer rainfalls appear to be driven by Sea Surface Temperature (SST) anomalies mainly in the Pacific, the Indian Ocean, the Mediterranean basin, and the North Pacific. A more detailed analysis shows that consistency of the spatial rainfall coherence is reduced during the onset season of the West African Monsoon.

Keywords: variability, rainfall, coherence, Saloum, Sahel

\section{Introduction}

The Sahel region in Western Africa is a semi-arid area located at the southern boundary of the Sahara desert and covered by grassland, shrubs, and small, thorny trees. The term is often applied to the whole region extending some $5000 \mathrm{~km}$ across Africa from the Atlantic coast to the Red Sea and from the Sahara to the humid savanna at roughly $10^{\circ} \mathrm{N}$. The Sahel is also sometimes defined as the area in which the mean daily rainfall is between 0.5 and $1.5 \mathrm{~mm}$, or in terms of annual mean, between 200 and $600 \mathrm{~mm}$ (Figure 1). In this study, as we focus on the western African monsoon, we define "Sahel" between the latitudes of 12 and $18^{\circ} \mathrm{N}$ and extending eastward up to $20^{\circ} \mathrm{E}$ (Figure 1). It includes much of the countries of Mauritania, Senegal, Mali, Niger, Chad Burkina Faso, and Nigeria. The climate variability over the Sahel region, which hosts about 70 millions of people, and which surface is equivalent to Europe, has been extensively documented during the past decades. Much attention is paid in particular to the monsoon season, which lasts from May to October 


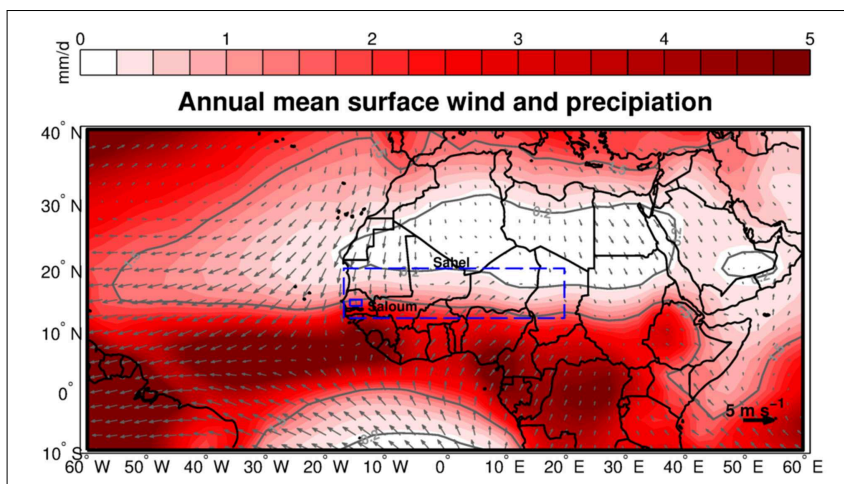

FIGURE 1 | Annual mean of precipitation (shaded, $\mathrm{mm} / \mathrm{d}$ ) and surface wind (vector, $\mathbf{m} / \mathbf{s}$ ). The blue rectangle shows the Sahel region defined in the text and the small blue rectangle indicates the location of Saloum River Delta. The 0.2 and $1.5 \mathrm{~mm} / \mathrm{d}$ isohyets are highlighted in gray contours.

north of the equator because of its crucial impact on agriculture and public health. Many studies were in particular motivated by the dramatic shift that the West African Monsoon (WAM) has experienced from wetter conditions in the 1950s and 1960s to much drier ones from the 1970s to the 1990s (e.g., Hulme, 1992; Lamb and Peppler, 1992; Nicholson et al., 2000; Le Barbé et al., 2002; L'Hôte et al., 2002; Dai et al., 2004). This drying is one of the most significant droughts at the regional scale observed during the twentieth century at a global scale (e.g., African Monsoon and Multidisciplinary Analyses International Scientific Steering Committee, 2005). Substantial variations of precipitations also occur at much shorter time scales, from daily to intraseasonal, with equally important consequences for the local resources (e.g., Sultan et al., 2005; Berg et al., 2009; Marteau, 2011).

The sub-seasonal, or intra-seasonal, rainfall variability during the summer monsoon season results from complex interactions between processes with various time and space scales (e.g., Diedhiou et al., 1999; Janicot et al., 2011). Intermittent regional modes have been identified, which represent an envelope modulating the occurrences of mesoscale convective systems (Laing and Fritsch, 1993, 1997; Hodges and Thorncroft, 1997; Mathon and Laurent, 2001). They are controlled on the one hand by internal atmospheric dynamics; in particular the development of synoptic scale African Easterly Waves (AEW; Reed et al., 1977; Duvel, 1990; Thorncroft and Hoskins, 1994a,b; Diedhiou et al., 1999; Kiladis et al., 2006) or synoptic scale Kelvin waves (Mounier et al., 2007). Monsoon flux and convection are significantly modulated by these waves (e.g., Fink and Reiner, 2003; Dieng et al., 2014).

At the seasonal time scale, West African climate is very sensitive to the continental surface boundary conditions (Charney and Shukla, 1981). Zheng and Eltahir (1998) document the impact of the vegetation distribution on West Africa Monsoon (WAM) system. In particular, they detail the impact of deforestation along the Guinean coast on surface net radiation and the reduction of boundary layer entropy, leading to weaker convection over the Sahel.

Although land surface processes might play a role also at even lower frequency, oceanic forcing is the dominant driver of the interannual to decadal WAM variability (Zeng et al., 1999; Biasutti et al., 2008). The El Niño-Southern Oscillation (ENSO) phenomenon (Janicot et al., 2001), the Atlantic Niño (Giannini et al., 2003) and the Mediterranean Sea (Rowell, 2003) have been identified to have an important impact on the WAM system and possibly on its predictability (Ward, 1998) on interannual time scales. Palmer (1986) suggested early a major influence of ENSO on Sahel precipitation. The teleconnection mechanism between the Tropical Pacific ocean and West Africa during warm ENSO events (El Niño) was explained with more details by Rowell (2001): the interaction of atmospheric equatorial Kelvin wave from the tropical Pacific with an off-equator Rossby wave (response to the zonal SST gradient between the East Indian Ocean and West Pacific) increases the large-scale subsidence over Africa. This weakens convective activity and thereby reduces the monsoon flow over West Africa. Nevertheless, this relationship is likely modulated by decadal variations of mean annual SSTs (Janicot et al., 2001).

More generally, at interannual to decadal time scale, several studies, including the pioneering works by Lamb (1978a,b) and Hastenrath (1984, 1990), and more recent modeling studies (e.g., Rowell et al., 1995; Vizy and Cook, 2002; Losada et al., 2010; Mohino et al., 2011) highlighted the influence of Sea Surface Temperature (SST) anomalies on precipitation variability over the Sahel. There is yet a debate on the location of the most important anomalies: Hoerling et al. (2006) attribute the drying of the 1980s to the interhemispheric gradient in the Atlantic Ocean, whereas Giannini et al. (2003) and Bader and Latif (2003) emphasize the role of the Indian Ocean. Other model studies indicated a relationship between changes in land-use and precipitation (Charney, 1975; Paeth et al., 2005, 2009; Abiodun et al., 2008; Davin and de Noblet-Ducoudré, 2010). In any case, knowledge of the interannual to decadal variability in the monsoon circulation is still quite limited (Afiesimama et al., 2006; Maloney and Shaman, 2008). The simulations of the fifth Coupled Model Intercomparison Project (CMIP5) confirm results from previous generations of models attributing a substantial role of anthropogenic emissions in driving precipitation changes in the Sahel (Biasutti, 2013). They also suggest that in a warming world, the WAM season may be shifted toward the end of the year, as they report a drying spring and wetting fall. Biasutti and Sobel (2009), Patricola and Cook (2010) and Monerie et al. $(2012,2013)$ similarly found a robust lag of the monsoon onset in the western Sahel together with an increase of the precipitation at the end of the season in the central African Sahel in the CMIP3 and CMIP5 climate models ensembles.

Episodic winter rainfall events, known as « heug $\gg$ or $\ll$ mango $\gg$ rain by the local population, also occur and affect mainly Cape Verde, Senegal and Mauritania between late October and March. These events are much less documented than summer precipitations, as they concern much more intermittent and weaker events. Nevertheless, they have had dramatic consequences in the past, causing floods and deaths among humans and cattle. A few studies based on observations (Seck, 1962; Gaye et al., 1994; Gaye and Fongang, 1997; Thorncroft and Flocas, 1997; De Félice, 1999; Knippertz and 
Fink, 2008) and models (Meier and Knippertz, 2009) found that winter rainfalls are associated to an intrusion of high level cold air masses from extratropics.

In spite of all these studies, the variability of Sahelian rainfall is still poorly constrained, partly because of the limited timespan of the instrumental record. In this regard, paleoclimate reconstructions are often of great help to better constrain the variability of poorly observed systems (Nicholson, 1994). However, there is a massive disequilibrium between our knowledge of long-term climate variability in northern continents and in Western Africa. Regarding the last 1000 years, several reconstructions of the northern hemisphere climate trends were put together from thousands of records from diverse archives, now yielding a relatively coherent picture of the past thermal variations over this regions (e.g., Fernández-Donado et al., 2013). Yet, only one marine coring site off the Senegal River (Mulitza et al., 2008) is available to document environmental changes during the last millennium in western Sahel. Using geochemical records from the sediments of Lake Bosumtwi, Ghana, Shanahan et al. (2009) proposed a reconstruction of the natural variability of the African monsoon over the past three millennia. Their study confirmed that intervals of severe drought lasting for periods ranging from decades to centuries are characteristic of the monsoon and are linked to natural variations in Atlantic temperatures. In the Saloum region, located on the Senegalese Atlantic coast (Figure 1) and highly sensitive to changes in the evaporation-precipitation budget, an exceptional opportunity for paleo-monsoon reconstruction is offered by the presence of fossil shell middens that can be used as high resolution archives (Azzoug et al., 2012a). Mollusks indeed record in the geochemistry of their shells the surrounding environmental conditions. Combining high resolution isotopic records with tidal growth increments, Azzoug et al. (2012b) showed that the duration of the rainy and dry seasons can be quantitatively estimated in the Saloum Delta over the last $\sim 2000$ years. While their work opens stimulating perspectives for the investigation of the seasonality of the WAM in the past, the relationship between local and regional rainfall variability needs to be assessed before extending paleoclimate reconstructions in the Saloum to the WAM in general. Precipitation is indeed known to be a patchy feature with small spatial scale (e.g., Houze and Cheng, 1977; Leary and Houze, 1979; Nicholson, 1995; Chen et al., 1996; Rickenbach and Rutledge, 1998; Lebel et al., 2009).

Here, we propose to test the spatial representativeness of precipitations measured locally over the Saloum Delta for the whole Sahel region at seasonal to decadal time scales. There is a strong east-west uniformity of climate and vegetation conditions in the Sahel. This is well illustrated by the regular zonal organization of the mean annual isohyets (Figure 1). The spatial coherence of annual and decadal anomalies is also very strong on the first order. Using 110 selected stations regularly distributed in West Africa and covering the years 1933-1940, Moron (1994) defined three main coherent regions at the peak of the sahelian rainy season: a "continental" Sahel, a "western" Sahel and a "Guinean" region, confirming previous analysis by Janicot (1992) and Nicholson and Palao (1993). Fontaine and Janicot (1996) later simplified this classification as they found that the western and continental Sahel rainfall anomalies were of the same sign for the majority of stations they analyzed. More recently, east-west contrasts have also been noted at decadal timescales (Dieppois et al., 2013) as well as at longer timescales, related to the long-term trends in response to climatic forcing (e.g., Lebel et al., 2009; Monerie et al., 2012; Biasutti, 2013).

For our analysis, we consider successively seasonal, interannual, and decadal time scales of modern records of precipitation over the region and we test how representative of the regional monsoon variability these local precipitations are. We also investigate the link of these local precipitation events with large scale SSTs. Results are interpreted in the light of present understanding of the dynamics of the WAM and heug rainfalls.

\section{Materials and Methods}

\section{Data}

Our analysis is primarily based on the monthly Global Precipitation Climatology Project (GPCP) version 2.2 (Adler et al., 2003; Huffman et al., 2009), which, under the World Climate Research Program (WCRP) and the Global Energy and Water Exchanges project (GEWEX), provides a global coverage with satellite and gauge information at $2.5^{\circ}$ resolution. More details about the dataset can be found at $\mathrm{ftp}$ //precip.gsfc.nasa.gov/pub/gpcp-v2.2/doc/V2.2_doc.pdf. We use the monthly data over the period [1979-2012].

In order to validate the robustness of our results, we use both the Tropical Rainfall Measuring Mission (TRMM) precipitations and records from two rain gauges located in the Saloum River Delta. In this study, TRMM precipitations version 3B42 (Huffman et al., 2007; Liu, 2015) are used, they contain output from the TRMM Algorithm 3B42 that are merged high quality (HQ)/infrared (IR) precipitation and root-mean-square (RMS) precipitation-error estimates. The output is given over $0.25 \times 0.25$ degree grid boxes daily. More details of the algorithm can be found here: http://trmm.gsfc.nasa.gov/3b42.html. We use the monthly data over the period [1998-2012]. Rain gauge data set was made available by the Regional Centre for the Improvement of Plant Adaptation to Drought (Centre Régional pour l'Amélioration de l'Adaptation à la Sécheresse (CERAAS), Salack et al., 2011). Two rain gauges located in the vicinity of the Saloum River Delta $\left(\left[14.5^{\circ} \mathrm{W}-14^{\circ} \mathrm{N}\right.\right.$ and $\left.\left.15^{\circ} \mathrm{W}-14.2^{\circ} \mathrm{N}\right]\right)$ were averaged and monthly data are used over the period [1979-2010].

Previous results have shown that GPCP and TRMM precipitation datasets have similar distribution patterns over the Tropics in spite of some differences in amplitude and location (Rui and Yunfei, 2005). Results show in particular that GPCP tends to underestimate the monthly precipitation over the land region with sparse rain gauges in contrast to regions with a higher density of rain gauge stations. The absolute bias between the two data sets is however less than $10 \%$ while the rain rate is less than $10 \mathrm{~mm} \mathrm{~d}^{-1}$.

The large-scale circulation and dynamics in the atmosphere and ocean surface associated to the precipitation variability are also investigated. For this, we use wind, geopotential height and outgoing longwave radiation (hereafter OLR) data from the 
operational analysis of the National Centers for Environmental Prediction (http://www.esrl.noaa.gov/psd/data/) at $2.5 \times 2.5^{\circ}$ latitude-longitude horizontal resolution (Kalnay et al., 1996). Monthly OLR data are used over the period [1979-2012] to analyze rainfall events in terms of atmospheric convection. Indeed more convective activity implies higher and colder cloud tops, which emit less infrared radiation into space. Hence, negative OLR anomalies indicate enhanced moist convection. Several evidences have already shown that OLR is a powerful proxy for the WAM onset (e.g., Fontaine et al., 2008). Finally, we used the Hadley Centre Global Sea Ice and SST (HadISST) dataset version 1.1 (Rayner et al., 2003), which is a monthly dataset of $1^{\circ} \times 1^{\circ}$ spatial resolution covering the period from 1870 to present.

\section{Data Processing and Time Scale Filtering}

In this study, we focus on the rainfall variability over the Saloum Delta and the Sahel regions respectively (Figure 1). The first region corresponds to the very small domain defined the $1^{\circ} \times$ $1^{\circ}$ region $\left[16^{\circ} \mathrm{W}-17^{\circ} \mathrm{W} ; 14^{\circ} \mathrm{N}-15^{\circ} \mathrm{N}\right]$. The second one is more regional, and corresponds to the average over the region $[18 \mathrm{~W}$ $\left.20^{\circ} \mathrm{E} ; 12^{\circ} \mathrm{N}-18^{\circ} \mathrm{N}\right]$. Averages over these to regions define the Saloum rainfall index and the Sahel rainfall index respectively.

Unless stated otherwise, we focus on two seasons. First, winter is defined here by the months January-February-March (JFM). Precipitation over the Saloum delta and the Sahel region are much more sporadic during this season. Nevertheless, the socalled "heug" rainfalls may have important local consequences and may also appear in paleo-records. The summer is then defined here by the months July-August-September. This is the monsoon season, during which rainfalls are most intense. Given the suggested sensitivity of the onset and demise seasons to external forcing (Biasutti and Sobel, 2009; Patricola and Cook, 2010; Monerie et al., 2012, 2013; Biasutti, 2013), and the sensitivity of the Saloum paleoclimate proxy to the duration of the rainy season (Azzoug et al., 2012b), we will also pay special attention to the onset and demise season defined over the months June-July (JJ) and September-October (SO) respectively.

In practice, the seasons defined above are retrieved from the whole dataset, linearly detrended and band-pass filtered in order to distinguish seasonal, interannual and decadal time scales: the seasonal band is isolated by applying a high-pass filter to the monthly data from the corresponding season with a cutoff frequency of 3 months. This is not the canonical definition of the seasonal timescale found in the literature because we use monthly data. However, our results show that it carries information significantly different from the interannual timescale. The interannual variability is extracted by considering 3-month averages for JFM and July-August-September (JAS) and a high-pass filter with a cutoff frequency of 8 years is applied to filter out the decadal variability. We also use 2-month averages for the specific case of the onset JJ and demise SO of the WAM. Finally, a lowpass filter is applied with a cutoff frequency of 8 years in order to capture the decadal variability and filter out the interannual variability. Decadal variability is not analyzed for the winter season due to the very intermittent character of winter events, as shown below.
For each time scale, regression between the normalized Saloum rainfall index and other variables are calculated. These regressions are computed as the covariance between the normalized index and specific variables, and are thus given in units of the given variable. This tool was preferred to correlations as it gives an indication of the amount of signal associated to the process under investigation. Significance of the regressions is tested with a bootstrap procedure (Monte Carlo technique). This procedure consists in randomly re-sampling the rainfall index to re-compute the regression. This is done a large amount of times so as to define the noise level. We show results that are significant at the $95 \%$ level, after 500 permutations. Monte Carlo simulation methods are especially useful in studying systems with a large number of coupled degrees of freedom, such as fluids.

\section{Validation of the Rainfall Indexes}

We first show the time evolution of rainfall averaged over the Saloum region during the period 1979-2012 for GPCP, 1979-2010 for the rain gauge and 1998-2012 for TRMM data respectively and for all seasons defined by 3 months averages (Figure 2, Top panels). Since the amount of winter rainfall is much smaller than summer rainfall, we represent the seasons running from October to May (Figures 2A,C) and the ones running from April to November (Figures 2B,D) separately, using two different color scales. The ratio among the scales indicates that summer events are of the order of 20 times larger than the winter events. This ratio holds for all three data sets, GPCP, the rain gauge and TRMM. The panels highlight a strong variability for summer and winter. In winter, important rainfall events are detected in 1993-1994 and in 2001-2002 (up to $0.2 \mathrm{~mm} /$ day) while practically no rainfall was detected between December and March from 1982 to 1990. In summer, precipitations are typically of the order of $6-8 \mathrm{~mm} /$ day in JAS, with substantial interannual variations. The monsoon season was particularly intense in 2000, in 2003 and in 2009, and it was particularly weak in 1983, 1991, 2002, and 2006.

For both seasons, and from 1998 onward, this variability is consistent in all three data sets. In summer, we note a slight shift in the 1999-2000 maximum: TRMM records a slightly weaker maximum, occurring in 2000 rather than 1999. The rain gauge records in fact two maxima, one in 1998 and one in 2000. TRMM also presents lower values by roughly $1 \mathrm{~mm} / \mathrm{d}$ for the 2003 maximum while the rain gauge values are stronger by $1 \mathrm{~mm} / \mathrm{d}$ as compared to the GPCP data. Note that this comparison between TRMM and GPCP differs from the results of Rui and Yunfei (2005) who rather found that GPCP tends to underestimate land precipitations as compared to TRMM. This could be due to the fact that we use here updated version of the two datasets. The difference in extreme values between the rain gauge and the GPCP might simply be due to the fact that the GPCP data set is based on objective analysis of station data which might have led to a smoothing of extreme values. Note that the winter event in 2002-2003 is on the other hand rather stronger in the GPCP as compared to the rain gauge records.

Figure 2 (bottom panels) shows the seasonal anomaly of these rainfall time series. The climatology is defined over the 


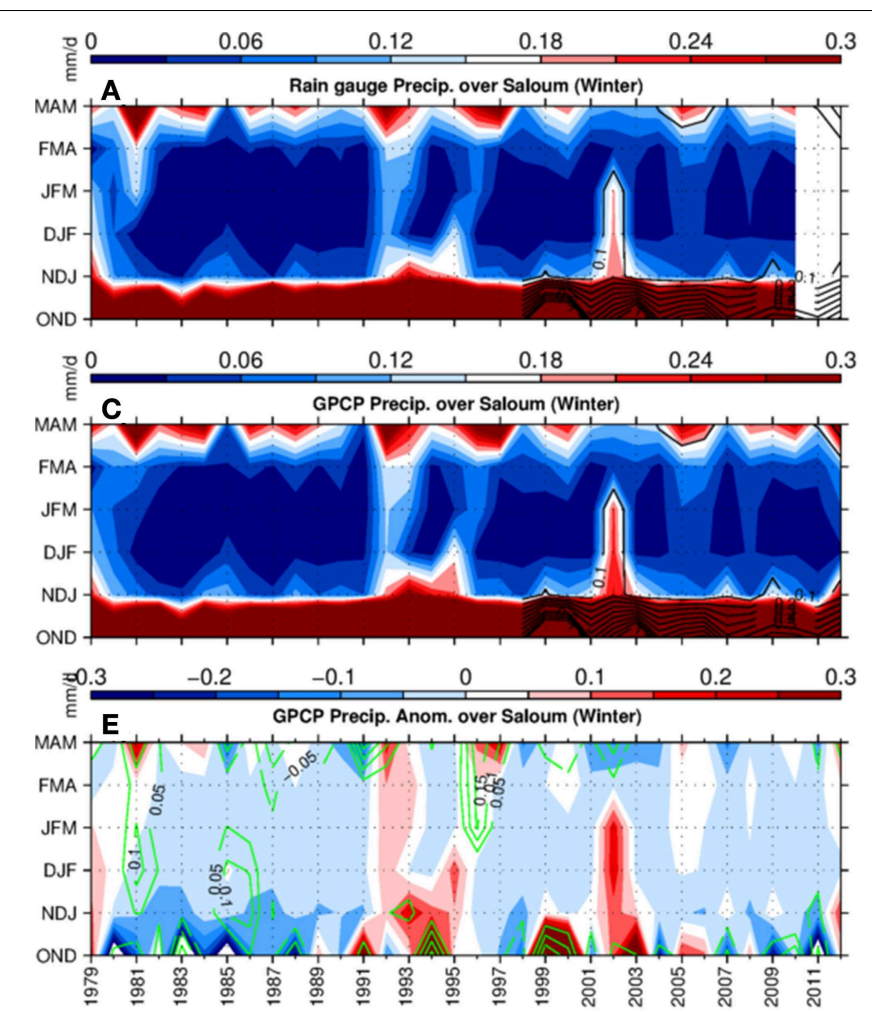

FIGURE 2 | Time evolution of the rainfall (shaded) in the Saloum region during winter for $(A)$ the rain gauge and $(C)$ for GPCP precipitation and during summer for (B) the rain gauge and (D) for GPCP precipitation. TRMM precipitations are shown in contours in all four panels. The vertical axis of the plot shows the different seasons of the year. Left Panels are centered over the winter season

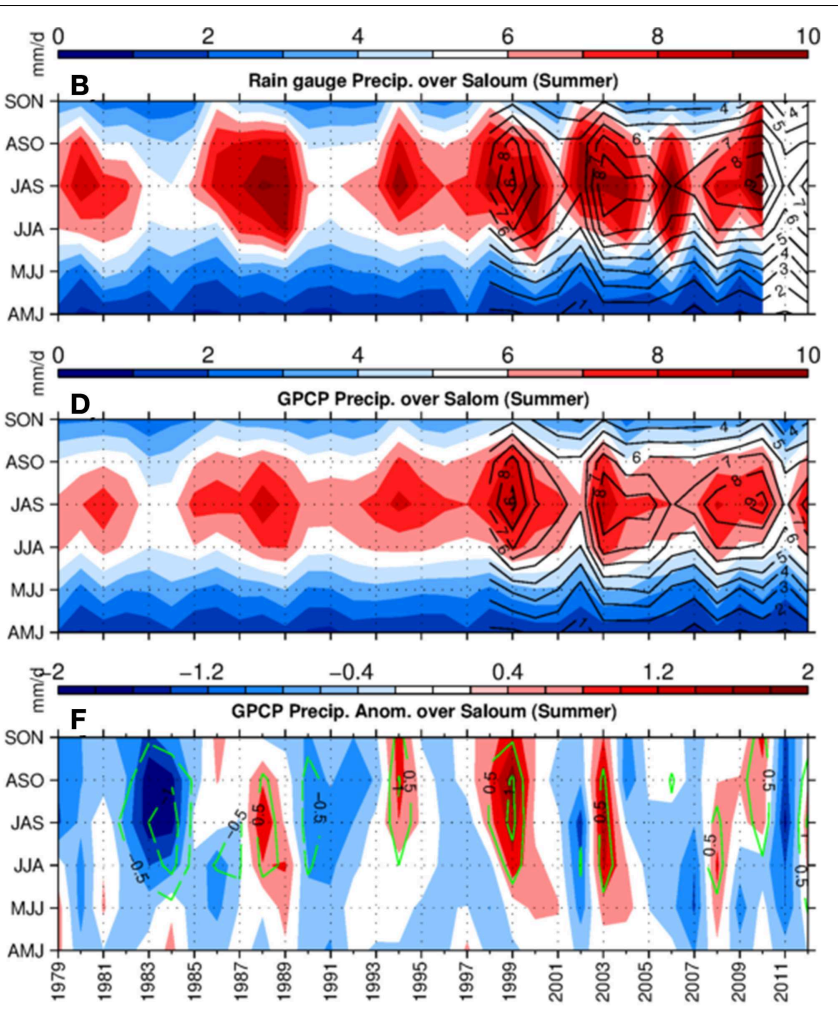

and right panels over the summer season, with adapted color scales. (E,F) Show GPCP precipitation anomalies, during winter and summer, respectively, calculated with respect to the seasonal cycle over the reference period 1979-2012. Anomalies averaged for the whole Sahel region computed over the same period with GPCP are superimposed in green contours. period [1979-2012] for GPCC and [1998-2012] for TRMM. The coherence of both time series is confirmed. TRMM slightly underestimates the winter maximum of 2001-2002 as compared to GPCP. This might be due to the length of record used to calculate the climatological mean (1979-2012 for GPCP and 1998-2012 for TRMM). Regarding the summer season, the temporal shift of 1999-2000 is again detected. The negative anomalies rainfall observed in 2007 in GPCP product reach their maximum value in 2006 in TRMM product. Beyond these slight differences, both precipitation records are rather consistent, as also discussed by Rui and Yunfei (2005) and give similar results in the analysis that follows. Therefore, and because of its longer temporal coverage, we focus on the GPCP data set in the following. Figure 2 (bottom panels) also shows that in general, the temporal sequence of rainfall anomalies over the Saloum region is not fully coherent with that of the whole Sahel region and especially during winter. Strong winter rainfall signal like in 2002 is clearly visible on the Saloum average but not in the Sahel region. On the other hand, winter rainfall events are detected in 1980, 1985, and 1995, but they are largely absent from the Saloum record. In summer (Figure 2D), the agreement is stronger, although some temporal shifts also exist. This preanalysis thus indicates that rainfall events over the Saloum region and over the whole Sahel region are not equivalent. In the following, we investigate more precisely the spatial and temporal domains over which Saloum rainfall are representative, and the associated mechanisms.

\section{Winter Rainfall Structure}

We examine here the spatial pattern associated with winter rainfall events over the Saloum region. For this, regression maps of precipitation over the eastern tropical Atlantic and western African continent with the Saloum rainfall index are represented for time scales from seasonal to interannual (Figure 3). At seasonal time scales (Figure 3, top), winter rainfall events over the Saloum region are significantly correlated with rainfall events over the Senegal and the southwestern half of Mauritania. This pattern extends over the ocean toward the southwest until roughly $20^{\circ} \mathrm{W}$ and $7^{\circ} \mathrm{N}$. Such northwest/southeast orientation for heug precipitation events is consistent with results from previous studies (Gaye and Fongang, 1997). In spite of small areas of significant regressions further east, the regression pattern generally does not extend over the whole Sahel region, as also found by Thorncroft and Flocas (1997), Gaye and Fongang (1997) and De Félice (1999). 


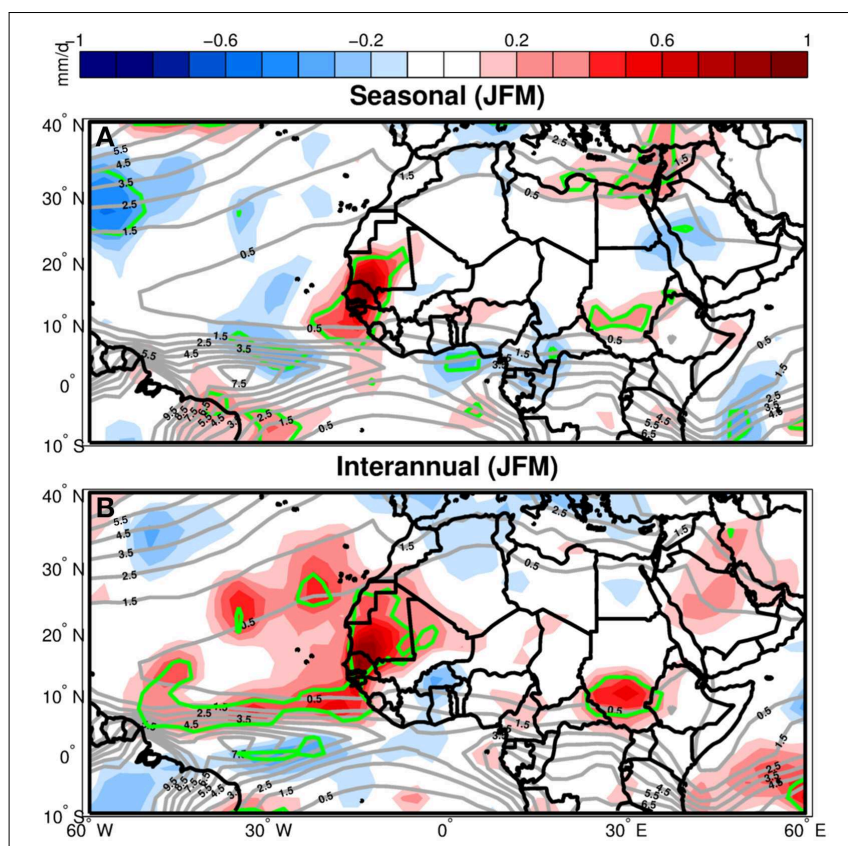

FIGURE 3 | Spatial regression (in $\mathrm{mm} /$ day) in winter (JFM) between Saloum rainfall and rainfall over the rest of the domain for (A) Seasonal, (B) Interannual time scale. Green contours delimit areas where the regression is significant at $95 \%$ level using a Monte Carlo simulation. Gray contours represent the mean (JFM) climatological rainfall $(\mathrm{mm} / \mathrm{d})$.

At interannual time scales, Saloum winter rainfall is also significantly correlated with adjacent areas in Senegal and the southwest Mauritania, but additionally, the pattern extends slightly eastward along the border between Mali and Mauritania as compared to higher frequencies. Interestingly, over the ocean, significant positive regressions are also found along about $10^{\circ} \mathrm{N}$ far to the west, and reach values of about 0.5 near Africa, right at the northern edge of the seasonal mean rainfall associated to the Inter Tropical Convergence Zone (ITCZ). This may indicate that interannual variability of heug events is associated with anomalous northward position of the eastern marine ITCZ. Yet, given that correlations over the oceanic extension amount 0.5 (not shown), this phenomenon could account for only about $25 \%$ of the winter Saloum winter rainfall variance.

In order to gain understanding on the dynamical origin of these winter rainfalls, we calculate the regression of the Saloum rainfall index with the OLR, the surface wind and the geopotential height at $400 \mathrm{mb}$ (Figure 4). At seasonal timescales, it is found that, land OLR regressions values are always negative with maxima around the Saloum region. As expected, it indicates that local precipitation is associated with cloud cover increase and enhanced atmospheric moisture. Furthermore, anomalous upper level geopotential height shows an anomalous low over the adjacent ocean, associated with a quasi-stationary disturbance of the mean distribution of the geopotential in the mid-latitudes. Over the Sahara, the southward extension of high pressures from the extratropics confirms the role of intrusions of air masses from the North in setting the winter rainfalls over the western Sahel region, as noted already by Seck (1962). At low-level,

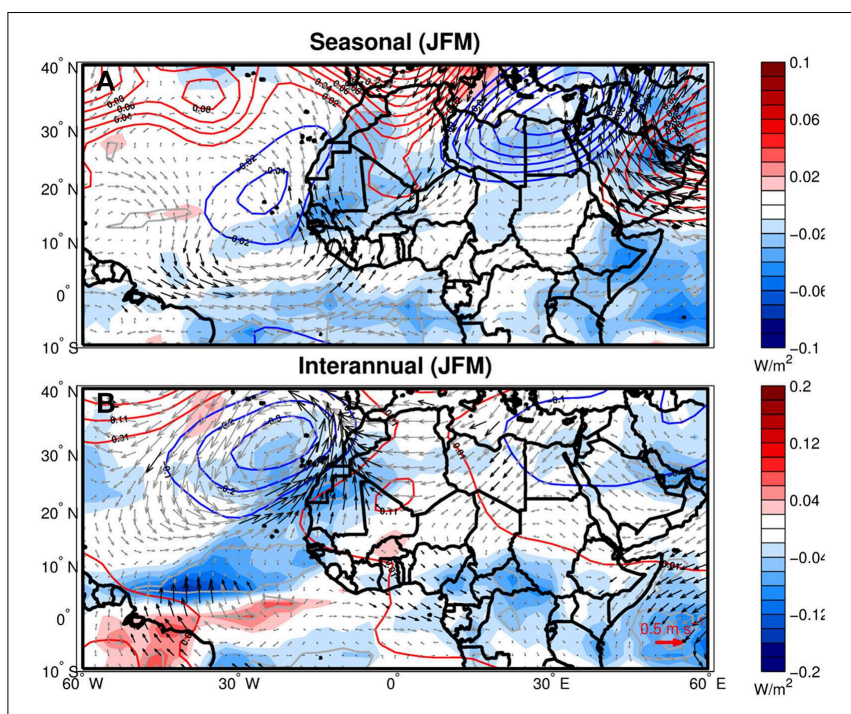

FIGURE 4 | Regression maps in winter (JFM) between Saloum rainfall index with OLR (shaded, W/m²), geopotential height at $400 \mathrm{hPa}$ (red: positive and blue: negative contours, $\mathrm{m}$ ) and $400 \mathrm{hPa}$ winds (vectors, m/s) for: (A) Seasonal; (B) Interannual time scale. Gray contours delimit areas where the OLR is significant at the $95 \%$ level using a Monte Carlo simulation.

moist southerlies enter the area. This situation favors the creation of unstable air mass and convective dynamics (Knippertz and Martin, 2005). At interannual timescales, anomalous OLR is mostly significant over the oceanic band. It is enhanced on the northern edge of the mean ITCZ and reduced on the southern edge, thereby confirming a northward shift of the eastern marine ITCZ. Locally, as for seasonal timescale, an upper level cyclonic disturbance is located to the west of the african continent while a poleward transport of tropical moisture is found at low-levels. Note that because of our use of monthly mean values, the anomalous geopotential structures found both at seasonal and interannual timescales are not significant at the 95\% level. Nevertheless, the dynamical elements are consistent with previous comprehensive studies of Knippertz and Martin (2005), Meier and Knippertz (2009) and Knippertz and Fink (2008), primarily based on single case-studies. To our knowledge, this is the first time that these mechanisms are described at lower frequencies.

\section{Monsoon Rainfall Structure}

\section{Sumer Rainfall}

We examine now the regression between Saloum rainfall index and rainfalls over the tropical Atlantic and adjacent african land during the season of the WAM. At seasonal time scales (Figure 5), regressions are positive, greater than $0.5 \mathrm{~mm} / \mathrm{d}$ and statistically significant up to Niger and Chad. This homogeneous regression over the Sahel region is similar to the results of Janicot et al. (2011, their Figure 5 at lag 0) computed from a Sahel index. Note however that this latter study uses daily data and thus includes shorter time scales than the one displayed here. 


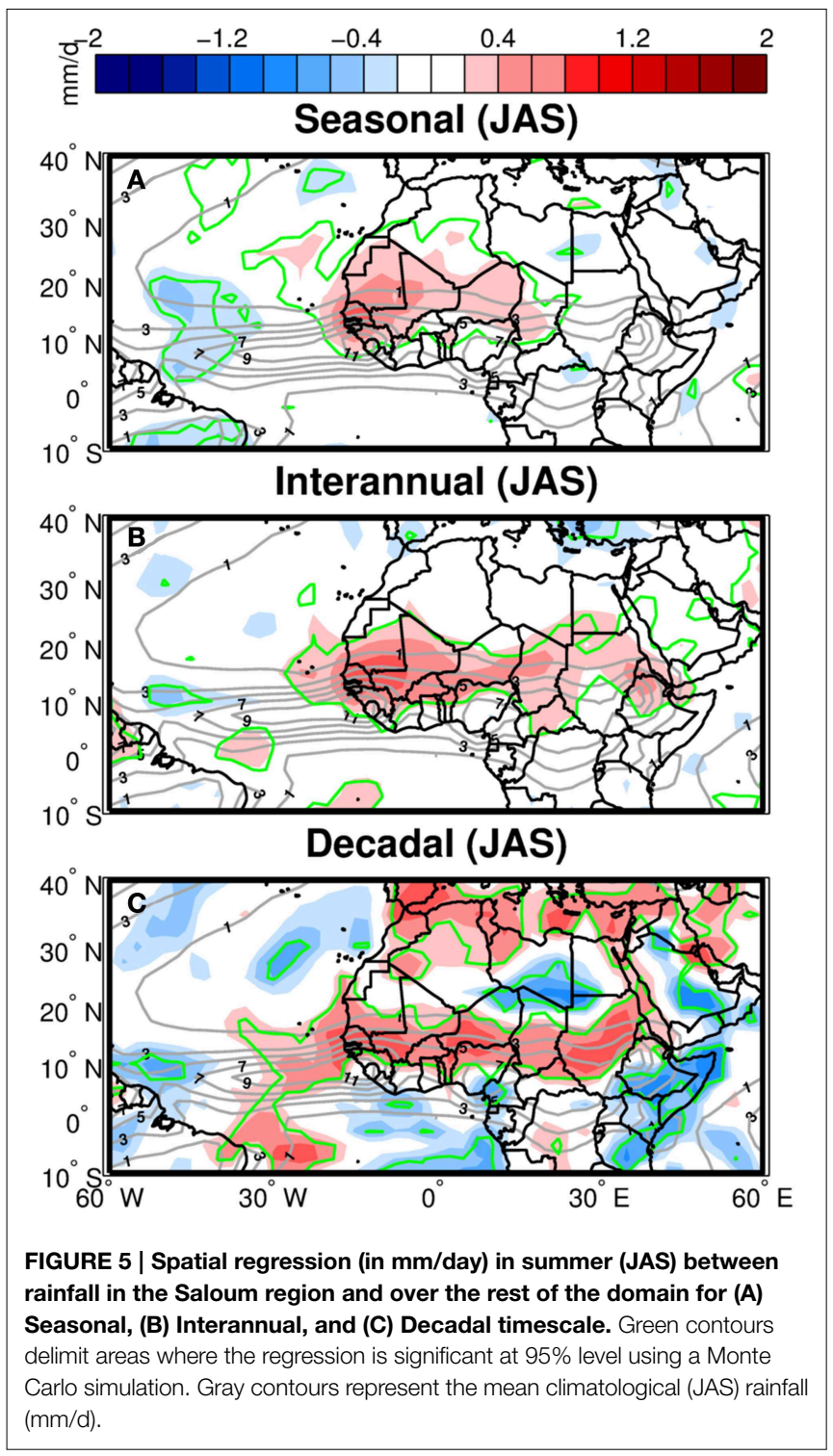

At interannual time scale, the significant regression pattern extends zonally eastward over the whole Sahel region up to eastern Africa, as well as westward over the Atlantic ocean. This is associated with the signature of the WAM at this time scale. Similar results are found for the decadal time scale, with more extended significant regressions over the adjacent ocean, until $40^{\circ} \mathrm{W}$ roughly and over the Mediterranean basin. At the sahelian latitude, a striking signal is observed above the tip of eastern Africa, where regressions are strongly negative. Decadal rainfall variability in Sahelian West Africa seems thus more out of phase with east-Africa than with the Gulf of Guinea area.

These results indicate that precipitation variability measured over the Saloum Delta are largely representative of the variability found over West Africa at seasonal timescales, and of the whole Sahel region at interannual and decadal scales. At all frequencies, the anomalous tropical precipitations are located at the northern edge of the mean ITCZ. This is confirmed on Figure 6 that

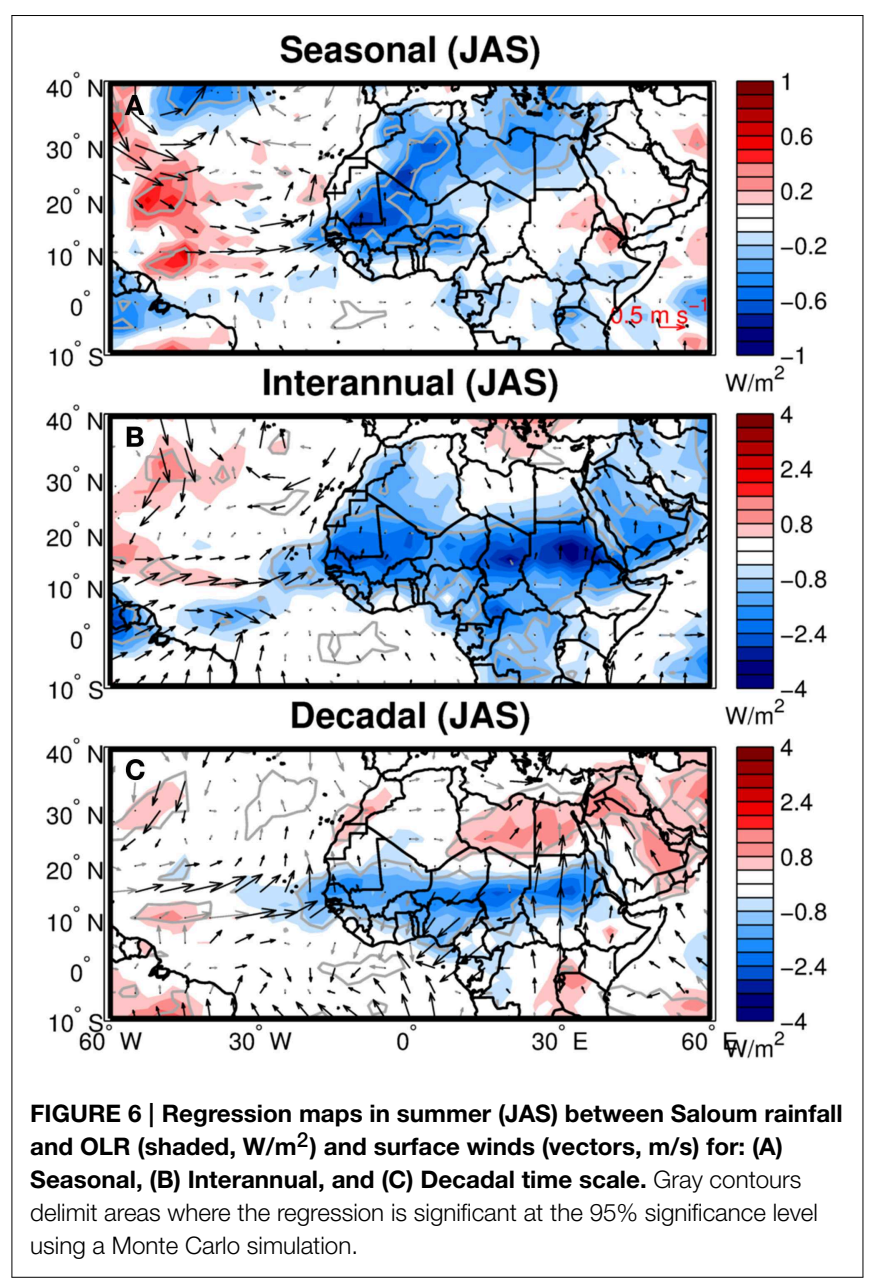

displays regression of OLR and surface winds on the summer Saloum rainfall index. At seasonal time scale, OLR exhibits a negative anomaly around Senegal, South of Mauritania and West of Mali (Figure 6A), suggesting deep atmospheric convection. This pattern is associated with a convergence of surface winds. This and the limited scale of the anomalous OLR pattern, indicate clearly that the seasonal rainfall anomalies are due to mesoscale convective systems. At interannual and decadal timescales, the convective signal extends further east over the Sahel region. Regressions are significant until as far as $15^{\circ} \mathrm{E}$, from about 10 to $20^{\circ} \mathrm{N}$ roughly. Significant regressions are observed over the ocean, consistently with the precipitation structures described in Figure 5. It is interesting to note a clear reduction in the intensity and extension of the negative OLR pattern from interannual to decadal scales which was not expected from the rainfall regression patterns. These findings show that at these time scales, rainfalls in the region are spatially coherent and are associated to large-scale atmospheric convection (ITCZ).

\section{Onset and Demise of the Rainfall Season}

In this section, we focus on the months leading in and out of the rainy season. Biasutti and Sobel (2009), Monerie et al. (2012) and Biasutti (2013) have indeed noticed a drying trend 
of the rainy season over the past decades, consistently with observations, in the CMIP3 models and the CMIP5 models, but also a delay in the rainy season in the future, with negative trends in the onset months (June-July, hereafter JJ) in particular over the western Sahel and positive trends in the demise months (September-October, hereafter SO) in the central Sahel (Biasutti, 2013). Although the topic has received some attention over the last years, including works on the predictability of the onset and demise dates (e.g., Laux et al., 2008) and association with atmospheric dynamics (Sultan and Janicot, 2003), these two seasons are less studied than the fully developed monsoon period.

Figure 7 shows the spatial coherence of Saloum rainfall during the onset and demise season at seasonal to decadal timescales. In June-July, Saloum precipitations are significantly correlated with regions locally confined over western Africa (Senegal and eastern Mali) and adjacent ocean. A few areas in the Central Sahel also show significant regressions. These patterns strongly resemble those obtained for winter rainfall variability (Figure 3), indicating a possible connection between winter rainfall season and the onset season. Although still significant over the western Africa, spatial regressions at decadal timescales on the onset season are not representative of any larger scale signal. No significant regression is found over the adjacent ocean. Regarding the end of the rainy season however, strong longitudinal and meridional coherence of rainfall over the whole Sahel region is obvious in Figure 7 at seasonal to decadal timescales. During this period, the WAM is in its southward displacement stage but still located in the Sahel, and zonal coherence of rainfall in the Sahel is therefore expected. These structures are similar to those obtained by Biasutti (2013) regarding the future trends of the onset and demise seasons: the onset of the WAM is more associated to local processes, while, when established, the monsoon events seem to enter its demise stage with an extended spatial coherency, which is observed at all timescales.

\section{Oceanic Forcings of the WAM}

Many studies have shown that the WAM over the Sahel region is associated with phenomena in neighboring regions, in particular the Mediterranean basin and the Tropical band over the Atlantic Ocean, but also the Pacific Ocean the Indian sub-continent and the African land. These teleconnections are found to be active from intraseasonal to multidecadal timescales (e.g., Lamb and Peppler, 1992; Janicot et al., 1998; Ward, 1998; Giannini et al., 2003; Losada et al., 2010). More specifically, several studies have focused on SST-driven variability of Sahel rainfall (e.g., Hoerling et al., 2006; Hagos and Cook, 2008; Caminade and Terray, 2009; Mohino et al., 2010; Rodríguez-Fonseca et al., 2011). Many significant links have been found, especially at seasonal to decadal timescales, and it has also been shown that, these teleconnections might evolve with time: for example, the sign of the regression

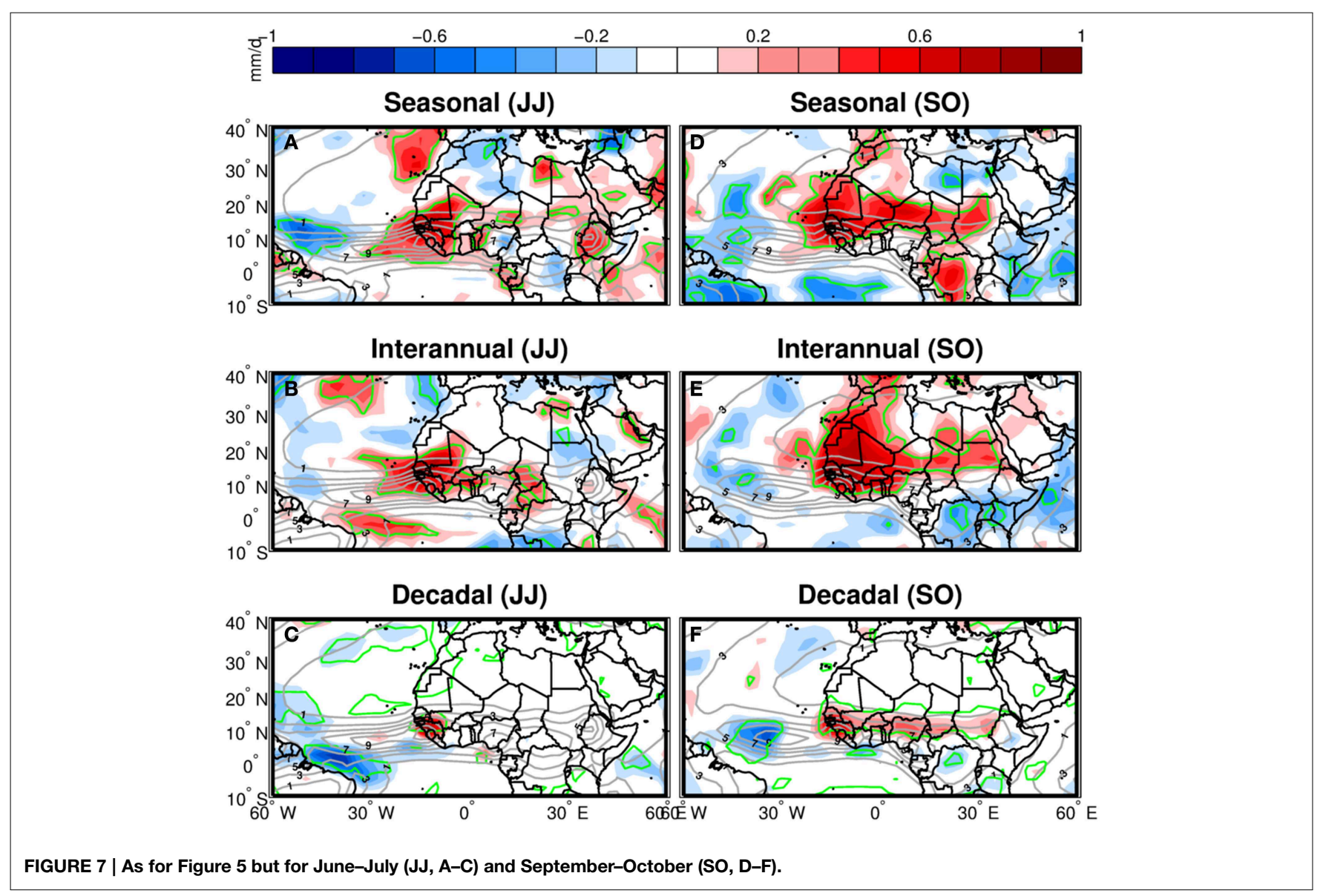


between SST anomalies in the equatorial Atlantic and in the Pacific has changed after the 1970s (Rodríguez-Fonseca et al., 2009).

In order to deepen our analysis of the relationship between the Saloum and the Sahel summer rainfalls, and to further gain confidence in the spatial coherency of summer precipitation patterns over Saloum with the WAM, we now investigate SST anomalies associated with precipitation anomalies over the Saloum region.

We propose an overview of similarities and differences between the SST patterns driving rainfalls locally and regionally respectively. Note nevertheless that distinguishing precisely among the different modes of variability is a complex topic that requires specific analysis (e.g., Mohino et al., 2010) and is beyond the scope of our study. We concentrate on the WAM season since no link between SST variability and the heug rainfall has been found (Seck, 1962; Meier and Knippertz, 2009). Figure 8 shows lagged-regression maps between the JAS Saloum rainfall index and global SSTs during the same season.

The SST regression maps associated to summer precipitation over the Saloum at seasonal time scale are patchy for negative lags. Significant anomalously warm SST anomalies are found in all tropical basins during the months preceding the precipitation signal but correlation values are rather weak (not shown). This structure is largely consistent with SST regressions over the Sahel index (not shown), although the tropical Pacific signal is stronger here. At lag zero however, a signal similar to the intraseasonal projection of the summer North Atlantic Oscillation (NAO, Keeley et al., 2009; Bladé et al., 2012) appears in the north Atlantic and is significant off North America, suggesting that seasonal variability over west Africa (see Figure 5) is linked to that of the northern Atlantic basin.

At interannual time scale, the SST structure leading anomalous summer precipitation over the Saloum shows more spatial coherency: significant anomalously warm SSTs are found mainly over the tropical southern Atlantic and the subtropical North Atlantic basin with an extension over the Mediterranean basin. Interestingly, no significant anomalies are found in the northern tropics, at the latitude of the Saloum. These structures are again very consistent with those obtained from the Sahel index except that signals in the Atlantic are much stronger and slightly shifted to the west in the Saloum case. Warm anomalies are also found in the western equatorial Pacific and they extend poleward above up to $30^{\circ}$ of latitude. Areas of negative regressions are found in the eastern equatorial Pacific indicating that at this time scale, El Niño (La Niña) events are typically associated with reduced (enhanced) WAM seasons a couple of months later. These anomalies are again very consistent with regressions using the Sahel rainfall index, but the areas of statistical significance are smaller here. The dominant influence of the tropical Pacific on the variability of the WAM at interannual timescales as indeed been shown in many studies (e.g., Giannini et al., 2003; Mohino et al., 2010; among others).

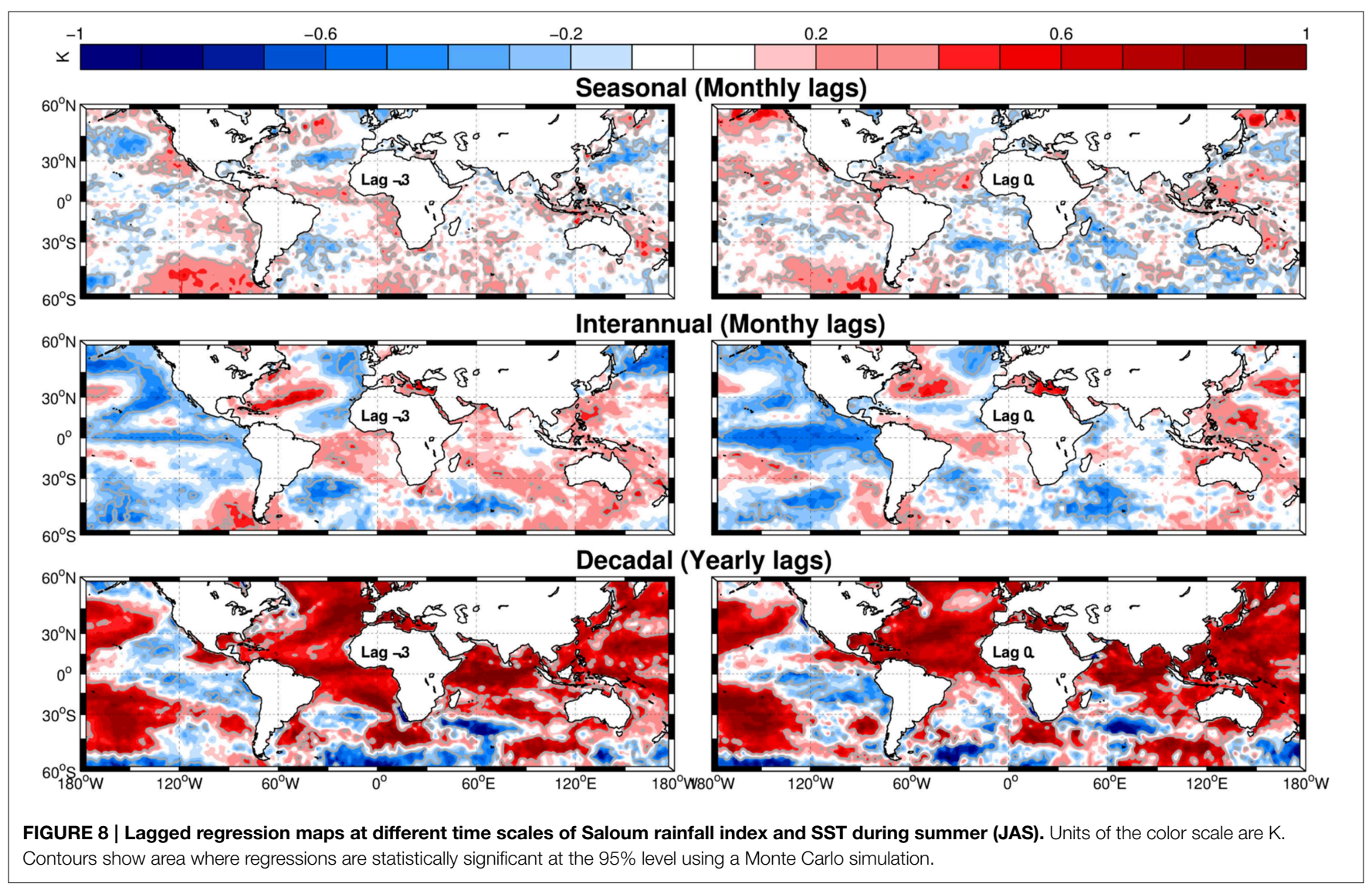


Here, we confirm a similar mechanism driving the rainy period locally over the Saloum Delta. In phase with the Saloum precipitation, significant SSTs anomalies are primarily found in the western Pacific, the northern tropical and the equatorial Atlantic. Lamb (1978a) and Vizy and Cook (2002) show a dipole pattern of precipitations in the Sahel and the Gulf of Guinea in which enhanced precipitations are associated with negative SST anomalies in the Equatorial Atlantic. It has recently been shown that, the sign of SST anomalies in the equatorial Atlantic associated to enhanced precipitation in the Sahel depends on the time period of analysis which opened the question about the non stationarity of the link between SST and precipitation (e.g., Rodríguez-Fonseca et al., 2011).

At decadal timescales, finally, precipitations over the Saloum regions are associated with warm oceanic anomalies over the tropical and subtropical Atlantic basin, the Indian Ocean and the Mediterranean basin. These findings confirm previous results regarding the influence of the Atlantic Multidecadal Oscillation (AMO, e.g., Folland et al., 1986; Rowell et al., 1995; Knight et al., 2006; Zhang and Delworth, 2006; Ting et al., 2009), the Interdecadal Pacific Oscillation (IPO, e.g., Mohino et al., 2010) and the Indian Decadal Variability (IDV, e.g., Bader and Latif, 2003; Giannini et al., 2003; Lu and Delworth, 2005; Mohino et al., 2010).

\section{Conclusions}

Azzoug et al. (2012b) recently opened promising perspectives with a new technique to quantitatively reconstruct the monsoon variability as well as the duration of the rainy and dry seasons in the Saloum Delta over the past millennia. Their methods are aimed at assessing the natural variability of the WAM over long periods. However, such generalization may deserve some care since precipitations are known to have patchy features with small spatial scale (Houze and Cheng, 1977; Leary and Houze, 1979; Nicholson, 1995; Chen et al., 1996; Rickenbach and Rutledge, 1998; Lebel et al., 2009). In this study, we show how the local Saloum rainfall is coherent with the regional Sahel rainfall at seasonal to decadal time scales. Results show that at seasonal time scale, the winter Saloum rainfalls known as "heug" or "mango" rainfalls, are not coherent over the whole Sahel region. It is representative of a limited area over western Africa, including Senegal, southern Mauritania and western Mali, and the oceanic regions adjacent to Senegal and Guinea. A slight increase of this domain is found at interannual time scale, in particular over the ocean where the signal seems to reveal a northward shift of the ITCZ. At all time scales, precipitations in winter are associated with an upper level anomalous cyclonic circulation to the west of the precipitative area and low level winds from the tropics potentially transporting moisture, and favoring convection. This is consistent with previous studies, which rather focus of specific case-studies.

During summer, Saloum rainfalls are more intense, and more coherent at the regional scale. At seasonal time scales, statistically significant regressions are found over the whole western half of sahelian Africa, including Niger. This finding is similar to the results of Janicot et al. (2011) computed from a Sahel index.
At interannual time scale, significant regressions encompass the whole sahelian band, and even extend westward over the ocean. Regressions increase at decadal time scale over the Sahel region. These results suggest a good consistency between Saloum and Sahel precipitation events during the monsoon season and tend to support the regional significance of local paleoclimate reconstructions in the Saloum.

Furthermore, in order to further deepen our understanding of the connection of the Saloum rainy season and the WAM, we have diagnosed the links between SST anomalies and Saloum rainfalls during the WAM season by computing laggedregression maps between the JAS Saloum rainfall index and global SSTs during the same season. At seasonal time scale, significant warm SST anomalies in the vicinity of the Saloum Delta are detected during the months preceding the precipitation signal, suggesting that local SSTs can play a role. Very weak SST signal can be seen over the equatorial Atlantic leading the seasonal Saloum rainfall variability. A horsehoe-like SST pattern in the North Atlantic in phase with the rainy season may be indicative of an influence of the NAO. These structures are largely consistent with SST regression over the Sahel index (not shown). At interannual time scale, precipitations over the Saloum region are typically associated with ENSO events in the tropical Pacific and warm anomalies over the equatorial and North tropical basins. At decadal time scale, AMO, IPV and possibly global warming are potential drivers of the Saloum rainfall variability, consistently with previous studies dedicated to the WAM.

On the other hand, analysis for the months of $\mathrm{JJ}$ and SO showed different behaviors for the onset and demise of the monsoon season. In June-July, precipitations in the Saloum region are significantly correlated with closely surroundings regions (Senegal and eastern Mali) but are not representative of the whole Sahel region. Nearly similar patterns were obtained during winter, indicating a possible connection between winter rainfall season and the onset season. Interestingly, as opposed to findings for other seasons, the spatial extent of the significant regression region tends to decrease at lower frequencies, suggesting that the decadal scale modulation of the early-WAM precipitation over the Saloum delta are local events. Regarding the termination of the rainy season, on the other hand, strong coherence is found over the whole Sahel region at seasonal to decadal time scales, consistently with results found for the fully developed WAM season.

Our study provides a framework for a more robust and accurate interpretation of recent paleoclimate proxies proposing a reconstruction of the monsoon seasonality in western Sahel. Our results show that proxy reconstructions of the monsoon season and its termination can generally be extrapolated to the Sahelian band. Furthermore, as indicated in the introduction, another proxy reconstruction of African rainfall has been proposed by Shanahan et al. (2009) from a sediment core taken in the lake Bosumtwi, Ghana. This location is further east and south than the Saloum Delta, and rainfalls are thus subject to different dynamics. Extension of the present study to this location may also be needed for a more accurate interpretation of this record. We emphasize that the spatial scale is also a crucial issue 
for applications such as crop yields or water resources. More generally, our study turns to the question of regionalization of the WAM region and downscaling (Paeth et al., 2011). Further work is, indeed, needed in order to better understand the regional coherence of the different phases of the WAM over the whole domain.

\section{References}

Abiodun, B. J., Pal, J. S., Afiesimama, E. A., Gutowski, W. J., and Adedoyin, A. (2008). Simulation of west African monsoon using RegCM3 Part II: impacts of deforestation and desertification. Theor. Appl. Climatol. 93, 245-261. doi: 10.1007/s00704-007-0333-1

Adler, R. F., Huffman, G. J., Chang, A., Ferraro, R., Xie, P., Janowiak, J., et al. (2003). The Version-2 Global Precipitation Climatology Project (GPCP) monthly precipitation analysis (1979-Present). J. Hydrometeorol. 4, 1147-1167.

Afiesimama, E. A., Pal, J. S., Abiodun, B. J., Gutowski, W. J., and Adedoyin, A. (2006). Simulation of West African monsoon using the RegCM3. Part I: model validation and interannual variability. Theor. Appl. Cimatol. 86, 23-37. doi: 10.1007/s00704-005-0202-8

African Monsoon and Multidisciplinary Analyses International Scientific Steering Committee, (AMMA ISSC). (2005). The International Science Plan for AMMA.

Azzoug, M., Carré, M., Chase, B. M., Deme, A., deMorais, L. T., Lazar, A., et al. (2012a). Positive Precipitation-Evaporation budget from AD 460 to 1090 in the Saloum Delta (Senegal), indicated by mollusk oxygen isotopes. Glob. Planet. Change 98-99, 54-62. doi: 10.1016/j.gloplacha.2012.08.003

Azzoug, M., Carré, M., and Schauer, A. J. (2012b). Reconstructing the duration of the West African Monsoon season from growth patterns and isotopic signals of shells of Anadara senilis (Saloum Delta, Senegal). Palaeogeogr. Palaeoclimatol. Palaeoecol. 346-347, 145-152. doi: 10.1016/j.palaeo.2012.06.001

Bader, J., and Latif, M. (2003). The impact of decadal-scale Indian Ocean sea surface temperature anomalies on Sahelian rainfall and the North Atlantic Oscillation. Geophys. Res. Lett. 30, 2169. doi: 10.1029/2003gl018426

Berg, A., Quirion, P., and Sultan, B. (2009). Can weather index drought insurance benefit to least developed countries' farmers? a case study on burkina faso. Weather Clim. Soc. 1, 71-84. doi: 10.1175/2009WCAS1008.1

Biasutti, M. (2013). Forced Sahel rainfall trends in the CMIP5 archive. J. Geophys. Res. 118, 1613-1623. doi: 10.1002/jgrd.50206

Biasutti, M., Held, I., Sobel, A., and Giannini, A. (2008). SST forcings and Sahel rainfall variability in simulations of the twentieth and twenty-first centuries. J. Clim. 21, 3471-3486. doi: 10.1175/2007JCLI1896.1

Biasutti, M., and Sobel, A. (2009). Delayed seasonal cycle and African monsoon in a warmer climate. Geophys. Res. Lett. 36, 707. doi: 10.1029/2009GL041303

Bladé, I., Liebmann, B., Fortuny, D., and van Oldenborgh, G. J. (2012). Observed and simulated impacts of the summer NAO in Europe: implications for projected drying in the Mediterranean region. Clim. Dyn. 39, 709-727. doi: 10.1007/s00382-011-1195-x

Caminade, C., and Terray, L. (2009). Twentieth century Sahel rainfall variability as simulated by the ARPEGE AGCM, and future changes. Clim. Dyn. 35, 75-94. doi: 10.1007/s00382-009-0545

Charney, J. G. (1975). Dynamics of deserts and drought in the Sahel. Q. J. R. Meteorol. Soc. 101, 193-202. doi: 10.1002/qj.49710142802

Charney, J. G., and Shukla, J. (1981). "Predictability of monsoons," in Monsoon Dynamics, eds J. Lighthill and R. P. Pearce (New York, NY: Cam Definition and predictability of an OLR-based West African monsoon onset bridge University Press), 99-109.

Chen, S. S., Houze, R. A. Jr., and Mapes, B. E. (1996). Multiscale variability of deep convection in relation to large-scale circulation in TOGA COARE. J. Atmos. Sci. 53, 1380-1409.

Dai, A., Trenberth, K. E., and Qian, T. (2004). A global data set of Palmer Drought Severity Index for 1870-2002: relationship with soil moisture and effects of surface warming. J. Hydrometeorology 5, 1117-1130.

\section{Acknowledgments}

This research was supported by the AWA program (Approche écosystémique de la gestion des pêches et de l'environnement marin dans les eaux ouest-africaines) and by CNRS-INSU LEFE program through the Saloum project (P.I. M.C.).

Davin, E. L., and de Noblet-Ducoudré, N. (2010). Climatic impact of global-scale deforestation: radiative versus non-radiative processes. J. Clim. 23, 97-112. doi: 10.1175/2009JCLI3102.1

De Félice, P. (1999). La Pluie au Sahel. Ecologie et Agronomie Appliquée, l'Harmattan. Paris.

Diedhiou, A., Janicot, S., Viltard, A., de Felice, P., and Laurent, H. (1999). Easterly wave regimes and associated convection over West Africa and tropical Atlantic: results from NCEP/NCAR and ECMWF reanalysis. Clim. Dyn. 15, 795-822. doi: $10.1007 / \mathrm{s} 003820050316$

Dieng, A. L., Eymard, L., Sall, S. M., Lazar, A., and Leduc-Leballeur, M. (2014). Analysis of strengthening and dissipating Mesoscale Convective Systems propagating off the West African coast. Mon. Weather Rev. 142, 4600-4623. doi: 10.1175/MWR-D-13-00388.1

Dieppois, B., Diedhiou, A., Durand, A., Fournier, M., Massei, N., Sebag, D., et al. (2013). Quasi-decadal signals of Sahel rainfall and West African monsoon since the mid-twentieth century. J Geophys. Res. Atmos. 118, 12587-12599. doi: 10.1002/2013JD019681

Duvel, J. P. (1990). Convection over tropical Africa and the Atlantic ocean during northern summer. Part, I. I. Modulation by easterly waves. Mon. Weather Rev. 118, 1855-1868.

Fernández-Donado, L. González-Rouco, J. F., Raible, C. C., Ammann, C. M., Barriopedro, D., García-Bustamante, E., et al. (2013). Large-scale temperature response to external forcing in simulations and reconstructions of the last millennium. Clim. Past 9, 393-421. doi: 10.5194/cp-9-393-2013

Fink, A. H., and Reiner, A. (2003). Spatiotemporal variability of the relation between African easterly waves and West African squall lines in 1998 and 1999. J. Geophys. Res. 108, ACL 5-1-5-17. doi: 10.1029/2002JD002816

Folland, C. K., Palmer, T. N., and Parker, D. E. (1986). Sahel rainfall and worldwide sea temperatures, 1901-85. Nature 320, 602-607. doi: 10.1038/320602a0

Fontaine, B., and Janicot, S. (1996). Sea surface temperature fields associated with West African rainfall anomaly types. J. Clim. 9, 2935-2940.

Fontaine, B., Louvet, S., and Roucou, P. (2008). Definition and predictability of an OLR-based West African monsoon onset. Int. J. Climatol. 28, 1787-1798. doi: $10.1002 /$ joc. 1674

Gaye, A. T., and Fongang, S. (1997). "Some aspects of interactions between tropical region and temperate zones in northern hemisphere winter season," in Proceedings 22nd Conference on Hurrican and Tropical Meteorology, (Colorado), 232-233.

Gaye, A. T., Fongang, S., Garba, A., and Badiane, D. (1994). Study of Heug rainfall in Senegal using conventional data and meteosat imagery. Veille Climatique Satellitaire 49, 61-71.

Giannini, A., Saravannan, R., and Chang, P. (2003). Oceanic forcing of Sahel rainfall on interannual to interdecadal time scales, Science 302, 1027-1030. doi: 10.1126/science. 1089357

Hagos, S., and Cook, K. (2008). Ocean warming and late-twentieth-century Sahel drought and recovery. J. Clim. 21, 3797-3814. doi: 10.1175/2008JCLI 2055.1

Hastenrath, S. (1984). Interannual variability and annual cycle. Mechanism of circulation and climate in the tropical Atlantic sector. Mon. Weather Rev. 112, 1097-1107.

Hastenrath, S. (1990). Decadal-scale changes of the circulation in the tropical Atlantic sector associated with Sahel drought. Int. J. Climatol. 10, 459-472. doi: 10.1002/joc.3370100504

Hodges, K. I., and Thorncroft, C. D. (1997). Distribution and statistics of African mesoscale convective weather systems based on ISCCP METEOSAT imagery. Mon. Weather Rev. 121, 2821-2837. 
Hoerling, M., Hurrell, J., Eischeid, J., and Phillips, A. (2006). Detection and attribution of 20th century northern and southern African rainfall change. J. Clim. 19, 3989-4008. doi: 10.1175/JCLI3842.1

Houze, R. A. Jr., and Cheng, C.-P. (1977). Radar characteristics of tropical convection observed during GATE: mean properties and trends over the summer season. Mon. Weather Rev. 105, 964-980.

Huffman, G. J., Adler, R. F., Bolvin, D. T., and Gu, G. (2009). Improving the global precipitation record: GPCP version 2.1. Geophys. Res. Lett. 36, L17808. doi: $10.1029 / 2009 \mathrm{gl} 040000$

Huffman, G. J., Bolvin, D. T., Nelkin, E. J., Wolff, D. B., Adler, R. F., Gu, G., et al. (2007). TheTRMM Multisatellite Precipitation Analysis (TMPA): Quasi-global, multiyear, combined-sensor precipitation estimates at fine scales. J. Hydrometeorol. 8, 38-55. doi: 10.1175/J HM560.1

Hulme, M. (1992). Rainfall changes in Africa: 1931-1960 to 1961-1990. Int. J. Climatol. 12, 685-699.

Janicot, S. (1992). Spatiotemporal variability of West African rainfall. Part I: regionalizations and typings. J. Clim. 5, 489-511.

Janicot, S., Caniaux, G., Chauvin, F., de Coetlogon, G., Fontaine, B., Hall, N., et al. (2011). Intraseasonal variability of the West African monsoon. Atmos. Sci. Lett. 12, 58-66. doi: 10.1002/asl.280

Janicot, S., Harzallah, A., Fontaine, B., and Moron, V. (1998). West African monsoon dynamics and eastern equatorial Atlantic and Pacific SST anomalies (1970-1988). J. Clim. 11, 1874-1882. doi: 10.1175/1520-0442-11. 8.1874

Janicot, S., Trzaska, S., and Poccard, I. (2001). Summer Sahel-ENSO teleconnection and decadal time scale SST variations. Clim. Dyn. 18, 303-320. doi: $10.1007 / \mathrm{s} 003820100172$

Kalnay, E., Kanamitsu, M., Kistler, R., Collins, W., Deaven, D., Gandin, L., et al. (1996). The NCEP/NCAR 40-Year Reanalysis Project. Bull. Am. Meteorol. Soc. $77,437-471$.

Keeley, S. P. E., Sutton, R. T., and Shaffrey, L. C. (2009). Does the North Atlantic Oscillation show unusual persistence on intraseasonal timescales? Geophys. Res. Lett. 36, L22706. doi: 10.1029/2009GL040367

Kiladis, G. N., Thorncroft, C. D., and Hall, N. M. (2006). Three dimensional structure and dynamics of African easterly waves. Part, I. Observations. J. Atmos. Sci. 63, 2212-2230.

Knight, J. R., Folland, C. K., and Scaife, A. A. (2006). Climate impacts of the Atlantic multidecadal oscillation. Geophys. Res. Lett. 33, L17706. doi: 10.1029/2006GL026242

Knippertz, P., and Fink, A. H. (2008). Dry-season precipitation in tropical West Africa and its relation to forcing from the extratropics. Mon. Weather Rev. 136, 3579-3596. doi: 10.1175/2008MWR2295.1

Knippertz, P., and Martin, J. E. (2005). Tropical plumes and extreme precipitation in subtropical and tropical West Africa. Q. J. R. Meteorol. Soc. 131, 2337-2365. doi: $10.1256 /$ qj.04.148

Laing, A. G., and Fritsch, J. M. (1993). Mesoscale convective complexes in Africa. Mon. Weather Rev. 121, 2254-2263.

Laing, A. G., and Fritsch, J. M. (1997). The global population of mesoscale convective complexes. Q. J. R. Meteorol. Soc. 123, 389-405. doi: 10.1002/qj.49712353807

Lamb, P. J. (1978a). Case studies of tropical Atlantic surface circulation patterns during recent sub-Saharan weather anomalies, 1967 and 1968. Mon. Weather Rev. 106, 482-491.

Lamb, P. J. (1978b). Large-scale tropical Atlantic surface circulation patterns associated with sub-Saharan weather anomalies. Tellus 30, 240-251. doi: 10.1111/j.2153-3490.1978.tb00839.x

Lamb, P. J., and Peppler, R. A. (1992). Further case studies of tropical Atlantic surface circulation patterns associated with sub-Saharan drought. J. Clim. 5, $476-488$.

Laux, P., Kunstmann, H., and Bárdossy, A. (2008). Predicting the regional onset of the rainy season in west africa. Int. J. Climatol. 20, 329-342. doi: $10.1002 /$ joc. 1542

Leary, C. A., and Houze, R. A. Jr. (1979). The structure and evolution of convection in a tropical cloud cluster. J. Atmos. Sci. 36, 437-457.

Le Barbé, L., Lebel, T., and Tapsoba, D. (2002). Rainfall Variability in West Africa during the years 1950-90. J. Clim. 15, 187-202. doi: 10.1175/15200442(2002)015<0187:RVIWAD > 2.0.CO;2
Lebel, T., Cappelaere, C., Galle, S., Hanan, N., Kergoat, L., Levis, S., et al. (2009). AMMA-CATCH studies in the Sahelian region of West-Africa: an overview. J. Hydrol. 375, 3-13. doi: 10.1016/j.jhydrol.2009.03.020

L'Hôte, Y., Mahé, G., Somé, B., and Triboulet, J. P. (2002). Analysis of a Sahelian annual rainfall index from 1896 to 2000; the drought continues. Hydrol. Sci. J.-J. Des. Sci. Hydrol. 47, 563-572.

Liu, Z. (2015). Comparison of precipitation estimates between Version 7 3-hourly TRMM Multi-Satellite Precipitation Analysis (TMPA) near-real-time and research products. Atmos. Res. 153, 119-133. doi: 10.1016/j.atmosres.2014.07.032

Losada, T., Rodriguez-Fonseca, B., Polo, I., Janicot, S., Gervois, S., Chauvin, F., et al. (2010). Tropical response to the Atlantic equatorial mode: AGCM multimodel approach. Clim. Dyn. 35, 45-52. doi: 10.1007/s00382-009-0624-6

$\mathrm{Lu}, \mathrm{J}$., and Delworth, R. (2005). Oceanic forcing of the late 20th century Sahel drought. Geophys. Res. Lett. 32, L22706. doi: 10.1029/2005GL023316

Maloney, E. D., and Shaman, J. (2008). Intraseasonal Variability of the West African Monsoon and Atlantic ITCZ. J. Clim. 21, 2898-2918. doi: 10.1175/2007JCLI1999.1

Marteau, R. (2011). Coherence Spatiale et Previsibilite Potentielle des Descripteurs Intra-Saisonniers de la Saison des Pluies en Afrique Soudano-Sahelienne: Application ala Culture du mil dans la Region de Niamey. Ph.D. thesis, University of Bourgogne.

Mathon, V., and Laurent, H. (2001). Lifecycle of Sahelian mesocale convective cloud systems. Q. J. R. Meteorol. Soc. 127, 377-406. doi: 10.1002/qj.49712757208

Meier, F., and Knippertz, P. (2009). Dynamics and predictability of a heavy dry season precipitation event over West Africa: sensitiviy studies with a global model. Mon. Weather Rev. 137, 189-206. doi: 10.1175/2008MWR2622.1

Mohino, E., Janicot, S., and Bader, J. (2010). Sahel rainfall and decadal to multidecadal sea surface temperature variability. Clim. Dyn. 37, 419-440. doi: 10.1009/s00382-010-0867-2

Mohino, E., Rodríguez-Fonseca, B., Losada, T., Gervois, S., Janicot, S., Bader, J., et al. (2011). SST-forced signals on West African rainfall from AGCM simulations-Part I: changes in the interannual modes and model intercomparison. Clim. Dyn. 37, 1707-1725. doi: 10.1007/s00382-0111093-2

Monerie, P.-A., Fontaine, B., and Roucou, P. (2012). Expected future changes in the African monsoon between 2030 and 2070 using some CMIP3 and CMIP5 models under a medium-low RCP scenario. J. Geophys. Res. 117:D16111. doi: 10.1029/2012JD017510

Monerie, P.-A., Roucou, P., and Fontaine, B. (2013). Mid-century effects of Climate Change on African monsoon dynamics using A1B emission scenario. Int. J. Climatol. 33, 881-896. doi: 10.1002/joc.3476

Moron, V. (1994). Guinean and Sahelian rainfall anomaly indices at annual and monthly time scales (1933-1990). Int. J. Climatol. 14, 325-341. doi: 10.1002/joc.3370140306

Mounier, F., Kiladis, G. N., and Janicot, S. (2007). Analysis of the dominant mode of convectively coupled Kelvin waves in the West African monsoon. J. Clim. 20, 1487-1503. doi: 10.1175/JCLI4059.1

Mulitza, S., Prange, M., Stuut, J. B., Zabel, M., Dobeneck, T. V., Itambi, A. C., et al. (2008). Sahel mega-droughts triggered by glacial slowdowns of Atlantic meridional overturning, Paleoceanography. Paleoceanography 23, PA4206. doi: 10.1029/2008PA001637

Nicholson, S. E. (1994). Century-scale series of standardized annual departures of African rainfall, in Trends (93): compendium of Data on Global Change. Carbon, 952-962.

Nicholson, S. E. (1995). "Environmental change within the historical period," in The Physical Geography of Africa, eds A. S. Goudie, W. M. Adams, and A. Orme (Oxford: Oxford University Press), 60-75.

Nicholson, S. E., and Palao, I. M. (1993). A re-evaluation of rainfall variability in the Sahel, Part, I. Characteristics of rainfall fluctuations. Int. J. Climatol. 13, 371-389. doi: 10.1002/joc.3370130403

Nicholson, S. E., Some, B., and Kone, B. (2000). An analysis of recent rainfall conditions in West Africa, including the rainy seasons of the $1997 \mathrm{El} \mathrm{Niño} \mathrm{and}$ the 1998 La Niña years. J. Clim. 13, 2628-2640.

Paeth, H., Born, K., Girmes, R., Podzun, R., and Jacob, D. (2009). Regional climate change in tropical and northern Africa due to green house forcing and land use changes. J. Clim. 22, 114-132. doi: 10.1175/2008JCLI2390.1 
Paeth, H., Born, K., Podzun, R., and Jacob, D. (2005). Regional dynamical downscaling over West Africa: model evaluation and comparison of wet and dry years. Meteorol Z 14, 349-367. doi: 10.1127/0941-2948/2005/0038

Paeth, H., Hall, N. M. J., Gaertner, M. A., Alonso, M. D., Moumouni, S., Polcher, J., et al. (2011). Progress in regional downscaling of West African precipitation. Atmos Sci. Lett. 12, 75-85. doi: 10.1002/asl.306

Palmer, T. N. (1986). Influence of the Atlantic, Pacific and Indian Oceans on Sahel rainfall. Nature 322, 251-253. doi: 10.1038/322251a0

Patricola, C. M., and Cook, K. H. (2010). Northern African Climate at the end of the 21st Century: integrated application of regional and global climate models. Clim Dyn. 35, 193-212. doi: 10.1007/s00382-009-0623-7

Rayner, N. A., Parker, D. E., Horton, E. B., Folland, C. K., Alexander, L. V., Rowell, D. P., et al. (2003). Global analyses of sea surface temperature, sea ice, and night marine air temperature since the late nineteenth century. J. Geophys. Res. Atmos. 108, 4407. doi: 10.1029/2002JD002670

Reed, R. J., Norquist, D. C., and Recker, E. E. (1977). The structure and properties of African wave disturbances as observed during Phase III of GATE. Mon. Weather Rev. 105, 334-342.

Rickenbach, T. M., and Rutledge, S. A. (1998). Convection in TOGA COARE: horizontal scale, morphology, and rainfall production. J. Atmos. Sci. 55, 2715-2729.

Rodriguez-Fonseca, B., Janicot, S., Mohino, E., Losada, T., Bader, J., Caminade, C., et al. (2011). Interannual and decadal SST forced responses of the West African monsoon. Atmos. Sci. Lett. 12, 67-74. doi: 10.1002/asl.308

Rodríguez-Fonseca, B., Polo, I., García-Serrano, J., Losada, T., Mohino, E., Mechoso, C., et al. (2009). Are Atlantic Niños enhancing Pacific ENSO events in recent decades? Geophys. Res. Lett. 36, L20705. doi: 10.1029/2009GL040048

Rowell, D. P. (2001). Teleconnections between the tropical Pacific and the Sahel. Q. J. R. Meteorol. Soc. 127, 1683-1706. doi: 10.1002/qj.49712757512

Rowell, D. P. (2003). The impact of Mediterranean SSTs on the Sahelian rainfall season. J. Clim. 16, 849-862. doi: 10.1175/15200442(2003)016<0849:tiomso>2.0.co;2

Rowell, D. P., Folland, C. K., Maskel, K., Owen, J. A., and Ward, M. N. (1995). Variability of the summer rainfall over tropical North Africa (1906-92): Observations and modeling. Q. J. R. Meteorol. Soc. 121, 669-704.

Rui, L., and Yunfei, F. (2005). Tropical precipitation estimated by GPCP and TRMM PR observations. Adv. Atmos. Sci. 22, 852-864. doi: 10.1007/BF02918685

Salack, S., Muller, B., and Gaye, A. T. (2011). Rain-based factors of high agricultural impacts over Senegal. Part, I. Integration of local to sub-regional trends and variability. Theor. Appl. Clim. 10, 1-22. doi: 10.1007/s00704-011-0414-z

Seck, A. (1962). Le Heug ou pluies de saison sèche au Sénégal. Ann. Geogr. 385, 225-246. doi: 10.3406/geo.1962.16196

Shanahan, T. M., Overpeck, J. T., Anchukaitis, K. J., Beck, J. W., Cole, J. E., Dettman, D. L., et al. (2009). Atlantic forcing of persistent drought in West Africa. Science 324, 377-380. doi: 10.1126/science.1166352
Sultan, B., Baron, C., Dingkuhn, M., and Janicot, S. (2005). Agricultural impacts of large-scale variability of the West African monsoon. Agric. For. Meteorol. 128, 93-110. doi: 10.1016/j.agrformet.2004. 08.005

Sultan, B., and Janicot, S. (2003). The West African monsoon dynamics. Part II: the "preonset" and "onset" of the summer monsoon. J. Clim. 16, 3389-3406. doi: 10.1175/1520-0442(2003)016<3389:TWAMDP> 2.0.CO;2

Thorncroft, C. D., and Flocas, H. A. (1997). A case study of Saharan cyclogenesis. Mon. Weather Rev. 125, 1147-1165.

Thorncroft, C. D., and Hoskins, B. J. (1994a). An idealized study of African easterly waves. Part, I. A linear view. Q. J. R. Meteorol. Soc. 120, 953-982. doi: 10.1002/qj.49712051809

Thorncroft, C. D., and Hoskins, B. J. (1994b). An idealized study of African easterly waves. Part, I. I. A nonlinear view. Q. J. R. Meteorol. Soc. 120, 983-1015. doi: 10.1002/qj.49712051810

Ting, M., Kushnir, Y., Seager, R., and Li, C. (2009). Forced and internal twentieth century SST trends in the North Atlantic. Clim. J. 22, 1469-1481. doi: 10.1175/2008JCLI2561.1

Vizy, E. K., and Cook, K. H. (2002). Development and application of a mesoscale climate model for the tropics: influence of sea surface température anomalies on the West African monsoon. J. Res. Atmos. 107, 22. doi: 10.1029/2001jd 000686

Ward, M. N. (1998). Diagnosis and short-lead time prediction of summer rainfall in tropical North Africa at interannual and multidecadal time scales. J. Clim. $11,3167-3191$

Zeng, N., Neelin, J. D., Lau, K. M., and Tucker, C. J. (1999). Enhancement of interdecadal climate variability in the Sahel by vegetation interaction. Science 286, 1537-1540. doi: 10.1126/science.286.5444.1537

Zhang, R., and Delworth, T. L. (2006). Impact of Atlantic multidecadal oscillations on India/Sahel rainfall and Atlantic hurricanes. Geophys. Res. Lett. 33. doi: $10.1029 / 2006 \mathrm{gl} 026267$

Zheng, X., and Eltahir, E. A. B. (1998). The Role of Vegetation in the Dynamics of West African Monsoons. J. Clim. 11, 2078-2096. doi: 10.1175/1520-044211.8.2078

Conflict of Interest Statement: The authors declare that the research was conducted in the absence of any commercial or financial relationships that could be construed as a potential conflict of interest.

Copyright (c) 2015 Wade, Mignot, Lazar, Gaye and Carré. This is an open-access article distributed under the terms of the Creative Commons Attribution License (CC $B Y)$. The use, distribution or reproduction in other forums is permitted, provided the original author(s) or licensor are credited and that the original publication in this journal is cited, in accordance with accepted academic practice. No use, distribution or reproduction is permitted which does not comply with these terms. 